\title{
E-Commerce Service Quality on Customer Satisfaction, Belief and Loyalty: A Proposal
}

\author{
Mutia Sobihah \\ Mahadzirah Mohamad \\ Nor Azman Mat Ali \\ Wan Zulqurnain Wan Ismail
}

Doi:10.5901/mjss.2015.v6n2p260

\begin{abstract}
E-commerce system websites have helped to grow the business into the international field. In the long term in view, it is very important for a business to manage satisfaction, belief, and customer loyalty in the adoption of E-commerce services for business development. In the hotel industry in Malaysia, there is lack of studies on the quality of E-commerce services and has prompted this study to be done. Examine the perception of foreign tourists to the service factors of E-commerce website that influence satisfaction, belief and loyalty are the main objective of this study. Adopting from the previous studies, a conceptual framework of the relationship between E-commerce service quality with satisfaction, belief, and customer loyalty in the hotel industry in Malaysia is established to adapt with this study. The tourism sector is the seventh major provider to the Malaysian economy, with a Gross National Income (GNI) of RM47.2 billion in the year 2013, and is the second leading foreign exchange recipient after manufacture goods. One of the tourism sectors is the hotel industries that have international dimensions and the use of the highest sites. Tourism and hotel industry in particular is a key-driver for economic growth because the industry has proven that it is a catalyst for development.
\end{abstract}

Keywords: customer loyalty, customer satisfaction, customer belief, E-commerce service quality, Malaysia hotel industry

\section{Introduction}

The developments of information technology and the internet is growing rapidly and is widely viewed as a key driving force to the increase in the use of E-commerce services in the world in general, and Malaysia in particular. In terms of access, E-commerce websites provide benefits to wider use of local consumers that moving internationally. E-commerce also provides new opportunities to export goods and provide services more widely. Besides that, E-commerce can improve and raise the level of efficiency in an organization. In 2010, the market size of E-commerce in Malaysia has reached RM1.8 billion, and will continue to increase up to RM5 billion in 2014. The development of E-commerce market size in Malaysia is RM2 billion to RM3 billion per year (Malaysiacrunch, 2013). The report also reveals that online purchases in the tourism industry are the most active in Malaysia at a cost of RM435 million, which is 24 percent compared to other industries (Internetworldstats, 2013).

The use of E-commerce in the hotel industry is seen can improve performance if satisfaction, and customer belief are met, and eventually customers will continue to be faithful to use it as a means of purchase. E-commerce website is one of the important strategies in business today. The service sector is an important sector in the Malaysian economy, which accounts for about 50 percent of Gross Domestic Product (GDP). Tourism industry is a contributor to socioeconomic development in Malaysia, and is the third largest contributor to total income after manufacturing in 2008 and 2009 (Ministry of Tourism, 2008 \& 2009). Increased between 2006 and 2010, tourism revenues by 55.6\% from RM36.3 billion to RM56.5 billion and foreign tourists increased by $41.4 \%$ from 17.4 to 24.6 million people (Tourism Malaysia: Facts \& Figures 2011). This information indicates that it is very important studies on loyalty, satisfaction and belief of foreign tourists in the quality of services offered in the tourism industry in general and hotels in particular. In line with Visit Malaysia Year 2014, this study was conducted to examine and identify the tourists who flock to the East Coast of Peninsular Malaysia that using the hotel or travel agency E-commerce websites to make room reservations, either they satisfied and have confidence with the E-commerce service websites. 


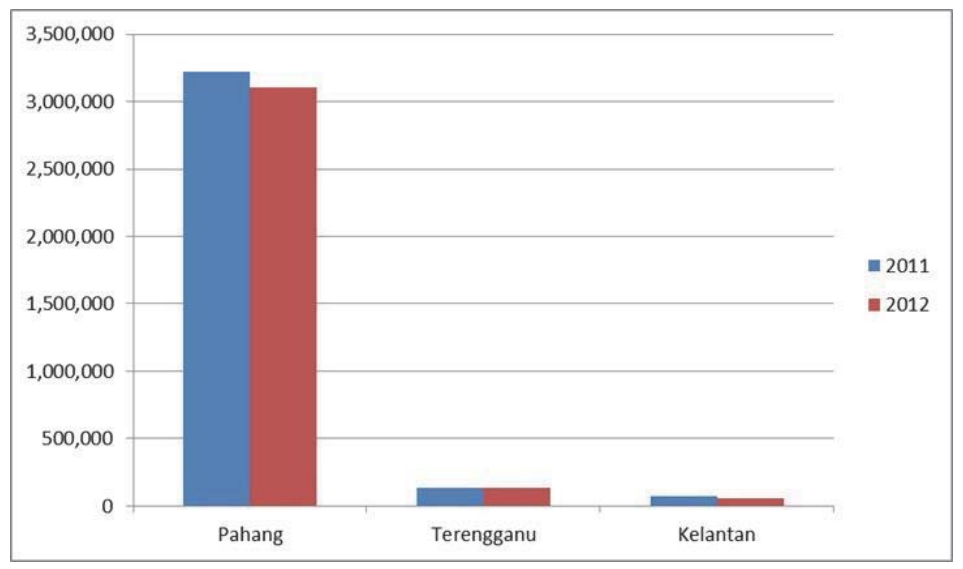

Figure 1. Number of Foreign Tourists Stay Hotel East Coast Malaysia (Tourism Malaysia, 2013)

The expansion rate of foreign tourists staying in hotels above three star on the East Coast of Peninsular Malaysia is positive except in 2012. Based on the graph 1, it was shown that the rate of foreign tourists staying in hotels at the East Coast of Peninsular Malaysia is decreased for the three states that is Pahang, Terengganu and Kelantan. In 2011, the number of foreign tourists staying at the hotel includes a total of 3,218,135 people and had dropped in 2012 to 3,107,088 people. While in Terengganu, the number of foreign tourists staying at the hotel in 2011 is estimated at 132,520 people and has declined to 132,407 people in 2012, and in the Kelantan number of foreign tourists staying at the hotel in 2011 was over 69,331 people and has dropped to 60,588 people in 2012. The decrease in occupancy rates in hotels may be due to several factors which include the lack of a unique destination, weaknesses of services offered by the hotel, lack of promotion, weak management, poor communication and technology (hotel websites and online booking) (NoorRaihan et al., 2011) . Therefore, this study will look and identify the notion of foreign tourists on the E-commerce service quality factors contributing to the low occupancy rate.

In the service sector, an efficient coordination was found that communication and information is a critical factor, therefore an efficient Internet technology has added value and has facilitated the service delivery. Competition in the hotel industry is how the values are delivered in the form of customer service quality of foreign and local tourists (NoorRaihan et al., 2011). Based on the analysis of previous studies, 35 to 40 percent of sales revenue from the E-commerce websites is from the repeated customers (Mustafa, 2011). Therefore, it is very important to know and determine the factors that influence customer loyalty in using the E-commerce website in the hotel industry.

These challenges and the competitive situation in the hotel industry need a better understanding of satisfaction, belief, and customer loyalty in achieving Malaysia as a reputable and preferred destination in Asia. Globally, customer loyalty typically has strong ties in increased profitability, and long-term development of an organization (Mustafa, 2011 and Reichheld, 1995). A small increase in the number of loyal customers can increase profits drastically within an organization (Huffmire, 2001).

Many empirical studies that examine the relation of satisfaction, belief, and customer loyalty as a result of Ecommerce service website received in many countries of the world due to its importance in terms of maintaining customer loyalty to the organization (Kim, Donald and Raghav Rao, 2009; Cyr, 2008, and Anderson and Srinivasan, 2003). Although there are empirical studies such as Mustafa (2011), and Ismail Kassim (2009), and Park and Kim, (2003), which was discussed on satisfaction, belief, and loyalty of E-commerce customers, but it is limited for the Malaysia hotel industry. To what extent E-commerce service quality affects satisfaction and customer belief in customer loyalty yet to be identified. Therefore this study will be undertaken to identify the factors of E-commerce service quality and its relationship with the satisfaction and belief of our clients in the hotel industry on the East Coast of Peninsular Malaysia.

\section{Literature Review}

\subsection{Customer loyalty}

Loyalty refers to the repetitive purchase of a product or service from the same brand. Oliver (1997) defines customer loyalty is when customers commit to buy back continuously and consistently in the future with the same brand. In the 
context of tourism, customer loyalty was loyalty to one's destination or traveling back and recommend to others through mouth-to-mouth (Kuenzel and Katsaris, 2009). Whereas in the context of E-commerce customer loyalty, it is very important and valuable. On this day, traders who use E-commerce websites, trying to find out how to construct customer loyalty. Loyal customers will be a source of information to other customers, they not only find information for themselves. Customer satisfaction and customer belief are some of the factors that can create customer loyalty that will contribute to the development of a long-term relationship between the customer and the E-service provider. The study by Kassim and Ismail (2009), relating to online customers find, the improvement in satisfaction and confidence, will give loyal customers. The work by Mustafa (2011) in Saudi Arabia, showing both variable between satisfaction and belief of our customers has a positive relationship with customer loyalty purchase through the E-commerce websites.

\subsection{E-commerce service quality}

Parasuraman et al., (1988) view service quality evaluation by the customers about their expectations of the services received by a particular service provider. While Santos (2003) defined E-commerce service quality as the evaluations from the actual experience of the service in terms of excellence and quality of the E-commerce service delivery in the online market. Wolfinbarger and Gilly (2002), developed comQ scale to measure E-commerce service quality. This scale consists of 14 items divided into four factors: web site design; reliability; privacy or security; customer service. Ecommerce service quality measures is to assess the quality of online web sites (Kuo, 2003), satisfied with the Ecommerce services that have been provided (Devaraj et al., 2002), and the determinants whether the website is successful or not (Liu and Arnett, 2000).

Referred to Gummerus et al., (2004), the user interface is the channel, where the users in relation to E-service providers. According to Kim and Lee (2002), the appeal the user interface design presents to their customers is illustrated in the form of web site design. The study by Mei Cao et al., (2005), have found that the elements of physical design such as information design, navigation, layout and appearance that is the software component are important but insufficient. Instead of the software component, the capability of the hardware also should be considered to make sure that the customers that access to the website can be loaded within tolerable time. Study by Srinivansan et al., (2002) has shown that interactive aspects of the applications of E-commerce has a strong relationship with customer loyalty.

Quality of product or service information can be defined as customers' perception on quality of service or product information supplied on the website (Park and Kim, 2003). Quality website content should be questioned because it is a way to give credibility to E-customer (Mustafa, 2011 and Mcknight et al., 2002). The study by Park and Kim, (2003), it was also found that the quality of information straightly affect customer satisfaction. The results of the research by Cyr (2008), found that culture also plays a role in the quality of information for customer satisfaction.

The notion of security response depends on the reliability of the method of payment and the manner of the transfer and storage of data, (Kolsaker and Payne, 2002). The notion of security vulnerabilities of E-commerce website by the customer will result in risk and a major difficulty to the E-commerce web site growth (Dong Her, 2004). Whereas according to Flavia'n and Guinaly'u, (2006), belief on the E-commerce website depends on the customers' notion of security of how E-commerce website manages their personal data. E-commerce websites can increase the belief of the customers by enhancing system security of E-commerce website, (Mustafa, 2011 and Warrington et al., 2000).

The notion of privacy can be defined as the capability of customers to control the existence of others, near the transaction process and the transaction process happen without the need to present themselves, (Goodwin, 1991). Whereas according to Flavia'n and Guinaly'u, (2006), the belief of the E-commerce websites are influenced by the notion of privacy by based customers on how organizations control their personal data. Privacy is the most serious issue in attracting more online potential customers and retains current customers (Park and Kim, 2003).

\subsection{Customer satisfaction}

Customer satisfaction is exactly how the customer satisfaction offered by the product or service. It has a close relationship with personal beliefs (Greyskens et al., 1996). Zins (2001), also states that loyalty can be developed through high level of customer satisfaction. However, the impacts of customer satisfaction on customer loyalty are complex. But according to Fisher (2001), customer satisfaction is only one reason, and is not an important reason why the customers will switch to other service or product. A study by Anderson and Lehmann, (1994), shows customer satisfactions are the main culprits in determining customer loyalty. Anderson and Srinivasan, (2003), found that the customer satisfaction and loyalty use of E-commerce website are affected by the belief and the perceived value which has been established by the company mutually. Studies of Cyr (2008) led also found that satisfaction with E-commerce websites is a key factor in 
maintaining customer loyalty.

\subsection{Customer belief}

A group of belief by online customers on online providers, and also the behavior of the suppliers in the upcoming (Coulter and Coulter, 2002). Meanwhile, according to Lee and Lin, (2005), suggests that the belief encourage virtual purchasing and indirectly it will affect the attitude of the purchase from E-wholesalers. Loyalty has contributed to the process of connecting and maintaining the value and importance of the relationship must be formed by belief, (Mustafa, 2011; Chaudhuri and Holbrook, 2001). The study by Cyr (2008) has found that in countries such as Germany and China shows, belief in the E-commerce website have a strong relationship with customer loyalty.

\subsection{The modified conceptual framework}

E-customer satisfaction and E-customer belief are mediating variables that will lead to E-customer loyalty towards B2C Ecommerce. The perceived user interface quality, the perceived product or service information quality, the notion of security risk, and the notion of privacy will affect E-customer satisfaction and E-customer belief. All these are illustrated in Figure 2, developed by Mustafa (2011).

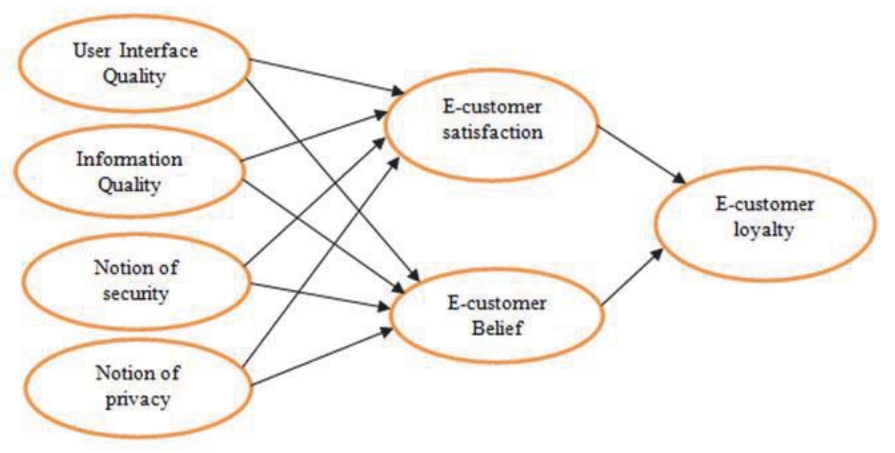

Figure 2. Conceptual Model of Determinants of E-commerce Customer Satisfaction, Belief and Loyalty in Saudi Arabia (Mustafa, 2011)

Based on the comQ scale that is developed by Wolfinbarger and Gilly (2002) in Figure 3, that divided the measurement of E-commerce service quality into four factors: web site design; reliability; privacy or security; customer service, this comQ scale and the instrument developed by Mustafa (2011) is adopt and a conceptual model is established to adapt with this study. In the established conceptual model, the perceived user interface quality, the perceived product or service information quality, the notion of security risk, and the notion of privacy will become the factors that will contribute to the E-commerce service quality or the factors to measure the E-commerce service quality as shown in Figure 4.

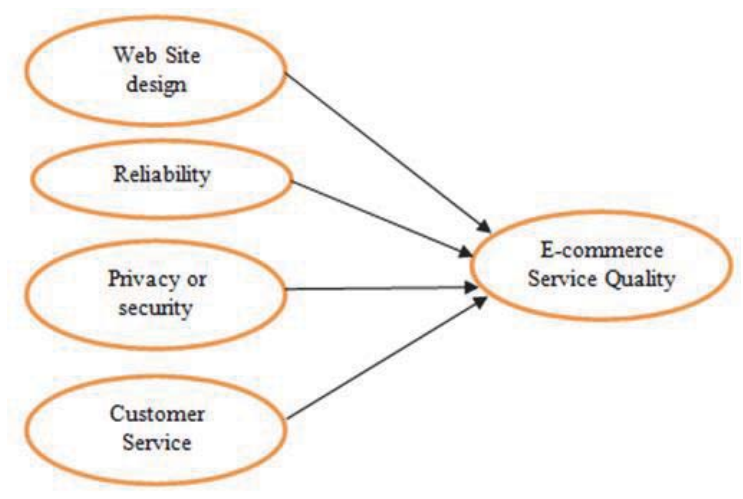

Figure 3. ComQ scale, measurement of E-commerce service quality (Wolfinbarger and Gilly, 2002) 


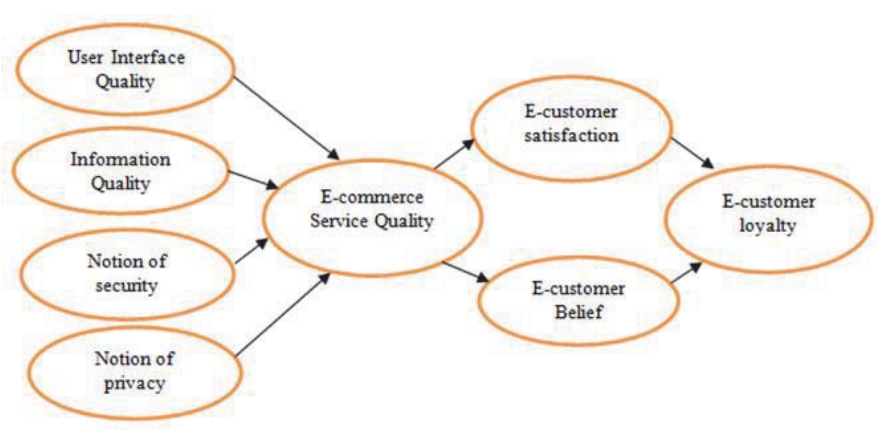

Figure 4. Conceptual Model of E-commerce Service Quality, Customer Satisfaction, Customer Belief and Customer Loyalty

Based on the conceptual model (Figure 4) and identifying the potential constructs and relationships among them, a set of propositions were developed:

$P 1$ The improved quality of E-commerce service is increasing tourist's satisfaction

$P 2$ The improved quality of E-commerce service is increasing tourist's belief

$P 2$ Customer satisfaction has a direct positive effect on customer loyalty

$P 3$ Customers beliefs have a direct positive effect on customer loyalty

The latent constructs were identified from previous studies. Table 1 shows the constructs and their measurement items.

Table 1. Constructs and measurement items from previous studies

\begin{tabular}{|c|c|}
\hline Construct & Measurement items \\
\hline \multirow{4}{*}{ User interface quality } & Convenient to use the Web site \\
\hline & Attractively displayed of information on the Web site \\
\hline & Visually attractive Web sites \\
\hline & My search effectiveness is increased by using the Web site \\
\hline \multirow{5}{*}{ Information quality } & The information of products or services that it sells on Web site is facilitates \\
\hline & Up-to-date products and services information must necessarily provide by the Web site \\
\hline & The relevant products/services information is provided by the Web site \\
\hline & The transaction on the Web site is easy to complete \\
\hline & An easy to understand information is presented by the Web site \\
\hline \multirow{4}{*}{ Notion of security } & To ensure the safe transmission of its users' information, the Web site has a mechanism \\
\hline & $\begin{array}{l}\text { To ensure the data I send cannot be modified by hackers, the Web site has sufficient } \\
\text { technical capacity }\end{array}$ \\
\hline & Financial risk will not occur by purchasing on the Web site \\
\hline & The Web site provide safe electronic payment \\
\hline \multirow{5}{*}{ Notion of privacy } & Personal data protection laws abides the Web site \\
\hline & Only user's personal data that are necessary is collected by the Web site \\
\hline & Without my consent, the Web site will not provide my personal information to others \\
\hline & When sending my personal information to the Web site, I feel safe \\
\hline & The privacy of the users is really concerned by the Web site \\
\hline \multirow{4}{*}{ E-customer satisfaction } & The Web site performance meets my anticipation \\
\hline & Sufficient experience is having by the Web site in marketing their products and services \\
\hline & To offer the products and services, the Web site knows their users well enough to adapt with their needs \\
\hline & To carry out its activities successfully, the Web site have enough resources \\
\hline \multirow{3}{*}{ E-customer belief } & The confidence in customers is inspires by the E-product/service provider \\
\hline & $\begin{array}{l}\text { The promises and commitments he assumes always fulfill by the E-product/service } \\
\text { provider } \\
\text { Giving the private information and the credit card number to the E-product/service provider is a problem }\end{array}$ \\
\hline & The Web site act opportunistically (e.g. gaining money unlawfully). \\
\hline \multirow{4}{*}{ E-customer } & In the near future, I will continuously purchase from the Web site \\
\hline & I will recommend the Electronic Commerce services to the others \\
\hline & My Electronic Commerce preference would not willingly change \\
\hline & Major rethinking required for changing my preference from the Electronic Commerce \\
\hline
\end{tabular}

Source: Mustafa (2011) 


\section{Methodology}

To carry out this study, we have chosen a quantitative research using a set of questionnaires as research instruments. Design survey used to collect primary data. The populations were tourists staying at the hotel and resort above three (3) star on the East Coast of Peninsular Malaysia. This study chose the hospitality industry because this industry is growing rapidly in Malaysia. Studies involving the hospitality industry in Malaysia is still a limited in determining satisfaction, belief in the quality of service E-commerce website thus creating loyalty E-customers.

The pilot study will be conducted on three (3) hotels, above three (3) stars in the state of Pahang to test the questionnaire's content validity. Through this pilot study, 100 respondents will be selected and given questionnaires before the actual study done. Respondents were foreign tourists who have reserved a hotel room online. According to Heiman (1998), a pilot study using respondent should have similarities in terms of shape, and features with the actual study respondents. Based on these reasons, the respondent of the pilot study have to meet the same criteria as well as the actual respondents.

The data collected will be tested by Confirmatory Factor Analysis (CFA) to assess the constructs before tested with goodness-fit model proposed study using SEM. AMOS software will be used when doing SEM to obtain the relationship between the constructs in the study simultaneously and will be tested with the proposed model. Goodness-of-Fit Index (GFI) and Adjusted Goodness of Fit Index (AGFI), will be used to find the goodness-of-fit of the proposed model. Baseline comparisons indexes, normed Fix Index (NFI), Tucker-Lewis Index (TLI) and the Comparative Fit Index (CFI), is another set of statistical goodness-of-fit, which will also be used to support the hypothesis model. Root Mean Square Error of the Approximation (RMSEA) for the proposed model will also be obtained to identify the appropriate error estimates for the model before the model is acceptable (Hair et al., 2006). SEM will also be used to test the hypotheses that have been proposed.

\section{Discussion and Conclusion}

This paper has sought to examine the perception of foreign tourists towards E-commerce service quality in Malaysian hotel websites that influence their satisfaction, belief and loyalty. Based on the discussions throughout this paper, it can be concluded that customer satisfaction and consumer belief will be influenced by E-commerce service quality and also the mediator that will influence customer loyalty in using the website as a substitute for traditional purchases.

This study will have practical implications for the hotel industry adopting E-commerce applications in Malaysia in general and on the East Coast of Peninsular Malaysia in particular. Malaysia hotel's manager can better understand the key factors of E-commerce applications or areas they should focus, in order to improve satisfaction, belief, and loyalty of online customers, thereby improving E-commerce services and corporate success. Besides that, this study also will have practical implications for education. The educators can know in which courses should give priority to achieve more successful Information Technology education. The revised framework in this study suggests that perceived user interface quality, the perceived product or service information quality, the notion of security risk, and the notion of privacy are the factors that determine the E-commerce service quality. In order to have a loyal customer, the hotel industry should fulfill the service quality expected by the customer that will satisfied and have belief with the service provider.

\section{Acknowledgement}

This research was supported by a research grant from Ministry of Higher Education [RAGS/2013/UNISZA/SS05/1], for which the author is indebted.

\section{References}

Anderson, F. And D. Lehmann, (1994). Customer Satisfaction, Market Share, and Profitability:Findings from Sweden, Journal of Marketing, Vol. 58, 3:53-66.

Anderson J. C. and S. S. Srinivasan (2000). E-satisfaction and E-loyalty: a Contigency Framework. Psychology \& Marketing, Vol. 20, 2:123-138.

Chaudhuri, A. \& M. Holbrook (2001). The chain of Effects from Brand Trust and Brand Affect to Brand Performane: The Role of Brand Loyalty. Journal of Marketing Vol. 65, 2:81-93.

Coulter, K. and R. Coulter, (2002). Determinants of Trust in a Service Provider: the Moderating Role of Length of Relationship, Journal of Services Marketing, Vol. 16, 1:35-50.

Cyr, D. (2008). Modeling Website Design Across Cultures: Relationships to Trust, Satisfaction and E-loyalty, Journal of Management 
Information Systems, Vol. 24, 4:47-72.

Devaraj, S., Fan, M. and Kohli, R. (2002), "Antecedents of B2C channel satisfaction and preference: validating e-commerce metrics", Information Systems Research, Vol. 13 No. 3, pp. 316-33.

Dong-Her, S., C. Hsiu-Sen, C. Chun-Yuan, and B. Lin, (2004). Internet Security: Malicious E-mails Detection and Protection, Industrial management \& Data Systems, Vol. 104, 7:613-23.

Fisher, A., (2001). Winning the Battle for Customers, Journal of Financial Services Marketing, Vol. 6, 2:77-83.

Flavia'n, C. dan M. Guinaly'U, (2006). Consumer Trust, Perceived Security and Privacy Policy: Three Basic Elements of Loyalty to a Web site, Industrial Management \& Data Systems, Vol. 106, 5:601-620.

Goodwin, C., (1991). Privacy: Recognition of a Consumer Right, Journal of Public policy Marketing, Vol. 10, 1:149-166.

Greyskens. i., J. Steenkamp, L. Scheer, and N. Kumar, (1996). The Effects of Trust and Interdependence on Relationship Commitment: a Trans-Atlantic Study, International Journal of Research in Marketing, Vol. 13, 4:303-317.

Gummerus, J., V. Liljander, M. Pura, A. Van Riel, (2004). Customer Loyalty to Content-Based Web Sites: The Case of an Online Healthcare Service, Journal of Service Marketing, Vol. 18, 3:175-186.

Hair, J. F. Jr., Black, W. C., Babin, B. J., \& Anderson, R. E. (2010). Multivariate Data Analysis, (7th ed.), New Jersey. Prentice Hall International, Inc.

Heiman, G. W. (1998). Understanding Research Method \& Statistic. An Integrated Introduction for Psychology. Houghton Mifflin Company, New York.

Huffmire, D. (2001). Improving Customer Satisfaction, Loyalty, and Profit : an intergrated Measurement and Management System.

Internet World Stats (2013). Pengguna Internet di Malaysia. http://wwww.internet worldstats.com. Capaian pada 18 Mei 2013.

Kassim, N. M. And S. Ismail (2009). Investigation the Complex Drivers of Loyalty in E-commerce Settings. Measuring Business Excellence, Vol. 13, 1:56-71.

Kim, D. J., L. F. Donald, and H. Raghav Rao. (2009). Trust and Satisfaction, Two Stepping Stones for Success E-commerce Relationship: A Longitudinal Exploration. Information System Research, Vol. 20, 2:237-257.

Kim, J. and Lee, J. (2002). Critical design factors for successful e-commerce systems. Behaviour and Information Technology, Vol. 21 No. 3, pp. 185-9.

Kolsaker, A. and C. Payne, (2002). Engendering trust in E-commerce: a study of Gender-Based Concerns, Marketing Intelligence \& Planning, Vol. 20, 4:206-214.

Kuenzel, S. and Katsaris, N. (2009).A Critical Analysis of Service Recovery Processes in the Hotel Industry, TMC Academic Journal, 4(1), 14-24.

Kuo, Y.F. (2003), "A study on service quality of virtual community web sites", Total Quality Management, Vol. 14 No. 4, pp. 461-73.

Lee, g. and H. Lin, (2005). Customer Perceptions of E-service Quality in Online Shopping,

International Journal of Retail and Distribution Management, Vol. 33, 2:161-176.

Liu, C. and Arnett, K.P. (2000), "Exploring the factors associated with web site success in the context of electronic commerce", Information and Management, Vol. 38 No. 1, pp. 23-33.

Malaysia Crunch (2013). Malaysia E-commerce Statistic. http://www.malaysia crunch.com/2012/3. Capaian pada 18 Mei 2013.

McKnight, D., V. Choudhury, and C. Kacmar, (2002). Developing and Validating Trust Measures for E-commerce: An Integrative Typology, Information Systems Research, Vol. 13, 3:334-359.

Mei Cao, Q. Z. (2005). B2C E-commerce web site quality: an empirical examination. Emerald Group Publishing Limited, 645-661.

Ministry of Tourism (2008). Malaysia Tourism Key Performance Indicators, 2008.

Ministry of Tourism (2009). Malaysia Tourism Key Performance Indicators, 2009.

Mustafa I. Eid., (2011). Determinant of E-commerce Customer Satisfaction, Trust, And Loyalty In Saudi Arabia. Journal of Electronic Commerce Research, Vol 12, No 1.

Noor Raihan Ab. Hamid, Aw, Y., \&RomizaMdAkhirf (2011).Dimensions of E-CRM.An empirical Study on hotel's web site.Journal of Southeast Asian Research.Vol. 2011.

Oliver, R. L. (1997). Satisfaction: A Behavioral Perspective on the Consumer. New York: The McGraw-Hill Companies Inc.

Parasuraman, A., Zeithhaml, V. and Berry, L. (1988), "SERVQUAL: a multiple-item scale for measuring consumer perceptions of services quality", Journal of Retailing, Vol. 64 No. 1, pp. 12-40.

Park, C. and Y. Kim, (2003). Identifying Key Factors Affecting Consumer Purchase Behavior in an Online Shopping Context, International Journal of Retail \& Distribution Management, Vol. 31, 1:16-29.

Reichheld, F. (1995). Renaissance of Marketing. Vol. 2, 4:10-21.

Srinivansan, S. S., R. E. Anderson, and K. Pannavolu, (2002).Customer Loyalty in E-commerce: an Exploration of its Antecedents and Consequences, Journal of Retailing, Vol. 78, 1:41-50.

Tourism Malaysia (2011). Research Facts \& Figure. http;//corporate tourism.gov.my. Capaian pada 27 June 2013.

Tourism Malaysia (2013). Research Facts \& Figure. http;//corporate tourism.gov.my. Capaian pada 274 June 2013.

Warrington, T., N. Abgrab, and H. Caldwell, (2000).Building Trust to Develop Competitive Advantage in E-business Relationships, Competitiveness Review, Vol. 10, 2:160-168.

Wolfinbarger, M. and Gilly, M.C. (2002), "COMQ: dimensionalizing, measuring and predicting quality of the e-tailing experience", MSI working paper series, no. 02-100, Marketing Science Institute, Boston, MA.

Zins, A., (2001). Relative Attitudes and Commitment in Customer Loyalty Models : Some Experience in the Commercial Airline Industry, International Journal of Service Industry Management, Vol. 12, 3:269-294. 